\title{
The Subject of Rural Areas in Croatian Daily Newspapers
}

\section{Doroteja Krivić}

\author{
Bukovački vijenac I. odvojak 5, 10000 Zagreb, Croatia, \\ $\mathrm{PhD}$ candidate at the postgraduate study in Agricultural Economics \\ E-mail:krivic.dorotea@gmail.com
}

Rade Šarović

University of Montenegro, Faculty of Philosophy, Danila Bojovića bb, 81400 Nikšić, Montenegro

Đurđica Žutinić

Doi:10.5901/mjss.2014.v5n13p87

University of Zagreb, Faculty of Agriculture, Svetošimunska 25, 10000 Zagreb, Croatia

\begin{abstract}
The mediatization of countryside has multiple effects on sociocultural, economic and political life of rural population. By spreading various and valuable information, the media can contribute to the awareness and education of rural population and accordingly immediately influence the development of rural communities. At the same time the media can significantly contribute to the knowledge of urban population about the importance of rural spaces and in this way contribute to wider global social affirmation of rural population. It is widely known that the printed media, unlike any other, offers the higher level of written subject analyticity. Therefore, the aim of this research is to find out the number of articles on the topic of village, their subjects and the purpose of publishing based on the example of daily Croatian newspapers. The research has been conducted on three national and two regional newspapers in Croatia, published in February and March 2012. The method of content analysis was used and the unit of analysis was newspaper article. The research proved the rare appearance of rural subjects. Only 111 of the total number of newspaper articles are of the rural thematic. Furthermore, there is no significant difference in the number of articles on the countryside topic published in national or in regional newspapers. In addition to that, it has been noted that national newspapers deal with issues of general national interest, while regional cover more local subjects connected with daily life. When considering countryside topics, the journalists of national newspapers tend to have sensationalist approach, on the other hand the articles of regional newspapers reflect the balance in intonation. That is the reason why non-sensational topics on countryside are less present in the daily national newspapers. As a consequence they are at the margins of media space.
\end{abstract}

Keywords: countryside, rural development, media

\section{Introduction}

A country promoting information among their citizens improves its own social development (Yadava, 1995). A key role in this process is played by the media, serving as an instrument for building democracy and as a tool for achieving important social changes (Yadava, 1995). Countries which set rural development as one of priorities can therefore achieve one with the help of media, being the catalyst of changes in rural areas. Mediatization of rural areas has multiple effects on political, economic and sociocultural life of rural population (Örs, 2008). Media can contribute to the awareness and education of rural population by spreading various and important information, and therefore immediately influence the development of rural communities. At the same time, media can have a significant influence on keeping the urban population up-to-date about the importance of rural space. Development journalism supports the role of media in this. The task of development journalist is to build a bridge between the rural and the urban (Šačić, 2003). Media are able to spread the voice of rural groups by giving importance to local subjects and in this way contribute to defining rural population as rightful citizens, and not as second-class citizens (Yadava, 1995). Accordingly, media has the power to contribute to bigger social affirmation of rural population.

We are familiar that printed media, in comparison with all the other media, make possible for a reader, as well as for a researcher, to get a bigger degree of analyticity of the event/ subject written. Former scientific research on the content analysis of Croatian daily newspapers did not give attention to the topic of village in media. In this research we will deal with how much the topic on rural area is present in Croatian newspapers. The aim is to investigate how much space the Croatian newspaper editorships dedicate to the topic of village and how they perceive it. In other words, if they 
promote social awareness through articles on the importance of rural development, or the purpose of these topics given is to achieve sensationalism, attracting reader's attention.

\section{The Aim and Hypothesis of Research}

Rural areas cover $91,5 \%$ of the territory of Croatia. About three quarters of the population lives in mostly rural and intermediate regions (Ministry of Agriculture, 2008). This should point out the importance of rural areas in the national development of the country. Therefore, the countryside thematic should be very much presented in media space of Croatian newspapers. The aim of this research is to find the number of articles on village, their topics and purpose of publishing, on the example of Croatian newspapers.

This work is based on the following assumptions:

$\mathrm{H1}$ : Rural thematic is presented in regional newspapers more than in national newspapers.

$\mathrm{H} 2$ : Rural thematic in Croatian newspapers is rarely present and mostly only then when creating sensationalism.

H3: Articles on rural topic were not credibly written.

\section{Sample and Method of Research}

Survey conducted by agencies GFK and PULS has shown that the most influential newspapers in Croatia are the following: Večernji list (38\%), Jutarnji list (27\%), Slobodna Dalmacija (11\%) and Novi list (6\%) (Dragojević, Kanižaj \& Žebec, 2006). Above mentioned newspapers have the highest reach, which marks the total number of readers who read and not necessarily also buy the newspapers. Congruently mentioned, sample covers three national (Jutarnji list, Večernji list and Vjesnik ${ }^{1}$ ) and two regional newspapers (Slobodna Dalmacija and Novi list) published in February and March 2012. We consider that the newspapers publish sensational topics in the beginning of the month, whereas less important topics at the end of the month. Newspapers published from the thirteenth to the twentieth of the month were analyzed due to objectivity. Analyzed were news editions published in Zagreb. Entertainment and sport sections were not included in the analysis, as well as feuilletons and similar enclosures which do not cover rural thematic.

The method of content analysis was used in the research. The analysis unit was a newspaper article chosen according to the occurrence of key words in the text (village, rural, agriculture, fishery, traditional, farmer, fisherman). According to the analysis, first we detected the position of an article on a newspaper page, type of article, intonation of article and article thematic. For the simplicity of defining context of village, the articles were sorted out in the following thematic units: agrarian politics, rural economy, criminal activity, accidents and local subjects ${ }^{2}$. Credibility of article is estimated according to the analysis of text authorship, number of sources and cited statements in the article. Regarding the cited statements, the attention was especially paid to the usage of quotation marks and delivering opposite opinions.

\section{Results of Research}

There were 111 articles on the topic of village in the analyzed newspapers. The largest number of articles was published by Slobodna Dalmacija (40), followed by Večernji list (27). Vjesnik published 17 articles and Novi list 16 articles. The least number of articles was published by Jutarni list (11). The newspaper profile contributed in great extent to the frequency of rural topics. Slobodna Dalmacija contains local columns (covering the towns of Zadar, Šibenik, Split and Dubrovnik, as well as their rural communities and the islands of Dalmatian archipelago). Večernji list is the national newspaper with long tradition of publishing and the aim of reporting about all the main events in the country. These include events of rural thematic. Jutarnji list is the newspaper with the most highlighted semi-tabloid format, so the emphasis is on the entertaining content and sports events, while the serious topics are set on the first few pages.

\subsection{Position and type of newspaper articles}

Position of article on a newspaper page is one of the key indicators of how editorship evaluates the topic. According to the survey, editorships of the analyzed newspapers chose to locate potentially sensational events on the front page. Rural thematic article was positioned only once on the front page, in the newspaper Večernji list with the articles about

\footnotetext{
${ }^{1}$ Although of modest publisher, Vjesnik has been used as a sample while their pages still hold the criteria of quality journalism. According to Croatian media experts, these are the most serious Croatian newspapers, with influence in political and diplomatic circles of Croatia. Moreover, these are the only newspapers not characterized by semi-tabloid format.

2 Thematic unit local subjects refer to topics about only specific village or rural region.
} 
economy issues in agricultural sector. However, the results of research (graph 1) showed that the majority of analyzed articles were positioned on the most read part of the page. The articles are mostly positioned in the upper part of the page, and then in the lower right part of the page. This was entirely contributed by the events from the period of analysis: milkmen protests due to low purchase price of milk, as well as disputes of Croatian fishermen with Slovenian government in the Bay of Piran.

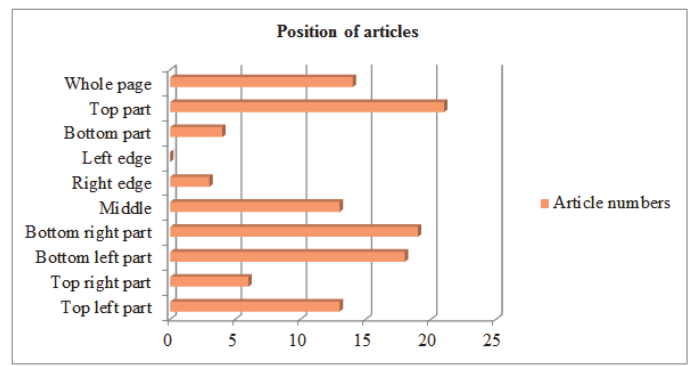

Graph 1. Position of articles on rural topics in daily newspapers

Type of article shows the prevailing forms of reporting in newspapers. The results of research (graph 2) show that editing politics of newspaper prefer neither interviews nor reportages, but the advantage is given to the reports in the form of short news (up to ten lines) or to half-page articles. These articles are often accompanied by photographs which will attract reader's attention.

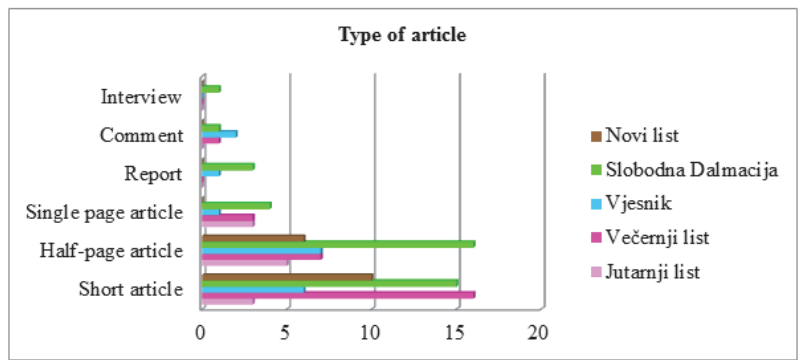

Graph 2. Type of article on rural topics in daily newspapers

\subsection{Topics and intonation of newspaper articles}

According to the results of research (table 1), national newspapers cover rural issues of national interest, while regional newspapers cover mostly local topics related to everyday life. Accordingly, regional newspapers give greater attention to local topics related to rural area of the region where the newspaper comes from.

Table 1. Article topics in daily newspapers

\begin{tabular}{|c|c|c|c|c|c|c|}
\hline \multirow[b]{2}{*}{ Newspapers } & \multicolumn{6}{|c|}{ Article topics } \\
\hline & Agrarian politics & Rural economy & Criminal activity in village & Accidents in village & $\begin{array}{c}\text { Local topics/events in } \\
\text { village }\end{array}$ & Total \\
\hline Jutarnji list & 1 & 6 & 0 & 1 & 3 & 11 \\
\hline Večernji list & 4 & 11 & 3 & 2 & 7 & 27 \\
\hline Vjesnik & 2 & 12 & 0 & 1 & 2 & 17 \\
\hline $\begin{array}{l}\text { Slobodna } \\
\text { Dalmacija }\end{array}$ & 4 & 10 & 3 & 0 & 23 & 40 \\
\hline Novi list & 2 & 8 & 1 & 1 & 4 & 16 \\
\hline Total & 13 & 47 & 7 & 5 & 39 & 111 \\
\hline
\end{tabular}


Intonation of article is considered to be a crucial element when creating the image of village in media space of the newspapers. Intonation is calculated by coefficient of imbalance. The research showed that the rural thematic in Croatian newspaper is presented in the negative tone (table 2). The negative tone is prevailing in Jutarnji list followed by Večernji list. Furthermore, Novi list and Slobodna Dalmacija contain mostly neutral tone towards rural topics. The analysis of thematic units showed that political topics have prevailingly negative tone which is the reflection of crisis in agricultural sector. Local topics have prevailingly positive tone due to events of entertaining character or to positive examples of successful agriculture reflecting brighter side of Croatian village. Only the thematic unit of accidents has neutral tone, being the part of accidents section where the journalist reports are based on information coming from the media announcements.

Table 2. Content analysis according to the intonation of article

\begin{tabular}{|l|c|c|c|c|c|c|}
\hline \multirow{2}{*}{ Topic of the article } & \multicolumn{5}{|c|}{ Newspapers } & \multirow{2}{*}{ Total } \\
\cline { 2 - 6 } & Jutarnji list & Večernji list & Vjesnik & Slobodna Dalmacija & Novi list & \\
\hline Agrarian politics & $1(0)$ & $4(-0,75)$ & $2(0)$ & $4(-0,75)$ & $2(-1,00)$ & $13(-0,62)$ \\
\hline Rural economy & $6(-0,83)$ & $11(-0,64)$ & $12(-0,25)$ & $10(-0,30)$ & $8(0)$ & $47(-0,38)$ \\
\hline Criminal activity in village & $0(-)$ & $3(0)$ & $0(-)$ & $3(-0,67)$ & $1(-1,00)$ & $7(-0,43)$ \\
\hline Accidents in village & $1(0)$ & $2(0)$ & $1(0)$ & - & $1(0)$ & $5(0)$ \\
\hline Local topics/events in village & $3(0,33)$ & $7(0,57)$ & $2(0)$ & $23(0,39)$ & $4(0,75)$ & $39(0,44)$ \\
\hline Total & $11(-0,36)$ & $27(-0,22)$ & $17(-0,18)$ & $40(0,03)$ & $16(0)$ & $111(-0,11)$ \\
\hline
\end{tabular}

\subsection{Credibility of articles}

Opinion of a reader created about an event depends on journalist's ability to deliver information through an article. In other words, news credibility demands a journalist's professionalism and knowledge about the subject he/she is reporting. Interpretation of a journalist can be appreciated in such an extent that some readers are buying a newspaper primarily because of a particular journalist or their column. For that reason is the authorship of a text an important segment in news credibility. The results of research (graph 3) show that the largest number of authorial articles were published in Slobodna Dalmacija, followed by Večernji list. Agency news, published by Croatian news agency (HINA), were represented in small number. Editorial texts were insignificantly present and they appear in each thematic unit.

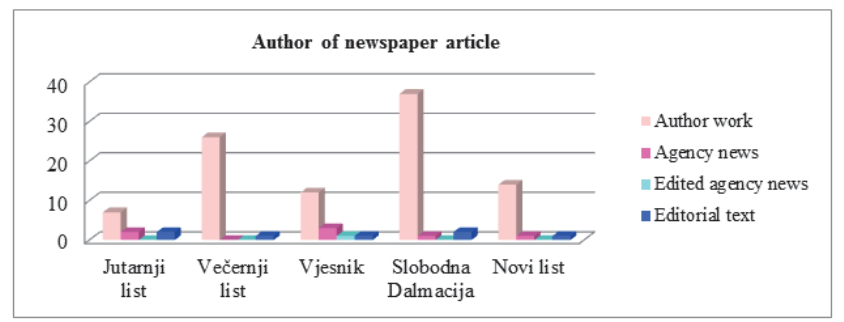

Graph 3. Author of newspaper article

Further detail authorship analysis showed that the only journalist following a rural thematic was a Vjesnik journalist. However, an engagement of a journalist for a specific subject, i.e. for milkmen protests, was noticed in Slobodna Dalmacija and Večernij list as well. Even more detailed authorship analysis focuses on the signature of an author. The articles were mostly signed with full name and surname, less frequently only with initials of both name and surname (graph 4). In Večernji list the authors leave their initials as signatures, especially in articles where they report on the subject of milkmen protests. Probably the author was assigned to report on likely unfamiliar subject, and gave his/her initials to avoid the possible criticism for the inadequate event interpretation. Furthermore, according to the analysis articles of local thematic signed with initials complete the newspaper page as a form of censorship. Since their title and content do not send clear message, one can conclude that they serve for distracting reader's attention from the more important article (so called story correspondence). 


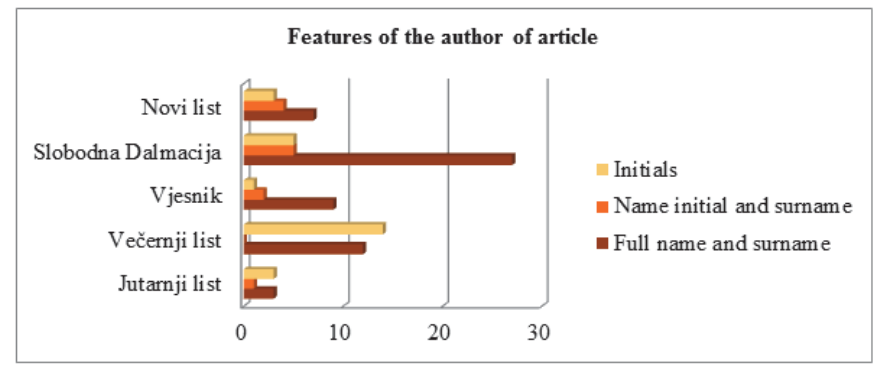

Graph 4. Author signature of newspaper article

Due to professionalism, a journalist has to refer in the article to at least two independent sources. Article consisting of news coming from one source is defined as propaganda or a journalist's review on the event (Malović, 2007). Our analysis showed that authors mostly rely on one source of information with the exception of Jutarnji list, consisting of articles without given source. Vjesnik and Slobodna Dalmacija use three and more sources equally (graph 5). Since Vjesnik is currently the Croatian newspaper with highest reputation, its editorship pays great attention to the quality of articles. Slobodna Dalmacija published the largest number of articles on rural thematic in the analyzed period, expectedly all the articles were of good content quality. However, even though the source is published, the element which diminishes the credibility of articles is the identification of a source by a journalist. When creating news, the journalists do not know, do not have enough time or they are not allowed to identify or use all the sources. The analyzed articles are mostly based on human sources of information, small number on secondary sources, and not a single one of them on primary sources of information ${ }^{3}$. We can assume that journalists do not enjoy complete freedom of reporting. The result is a superficially processed topic and an article of low quality.

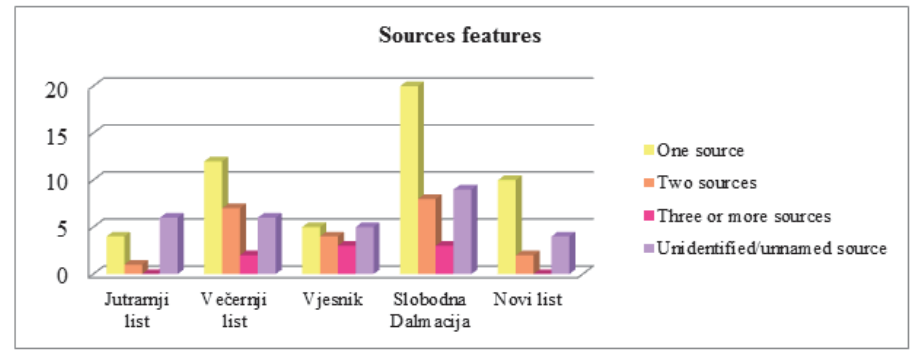

Graph 5. Number of sources of the articles in daily newspapers

Vacillation between journalism ethics and race for profit makes it difficult for editorship to achieve balance between a responsible journalist and news which gains profit (Poler Kovačić, 2001). As a result, journalists use, among other, quotations to prove the credibility of articles. According to the results (table 3), one person is the most frequently cited several times. Then follow texts without quotations. There is the least number of texts with three or more people cited. Content analysis proved that Croatian editorships prefer literal citing of individuals with the usage of quotation marks. This is especially evident when expressing contradictory opinions. Semi-tabloid format of Croatian newspapers indicates summed-up delivery of events whereas the quality of event interpretation is in the background.

\footnotetext{
3 Phases in source identification of a research process are possible to describe like concentration circles: outer circle consists of secondary sources of information (news archive, online information), whereas in the inner circle are the primary sources of information (Obad, 2004).
} 
Table 3. Use of quotes in newspaper articles on rural topic

\begin{tabular}{lccccc}
\hline Newspapers & No quotes & One person quoted & Two persons quoted & Three or more persons quoted & Total \\
\hline Jutarnji list & 3 & 5 & 3 & 0 & 11 \\
Večernji list & 7 & 13 & 5 & 2 & 27 \\
Vjesnik & 9 & 5 & 3 & 0 & 17 \\
Slobodna Dalmacija & 11 & 17 & 9 & 3 & 40 \\
Novi list & 6 & 8 & 1 & 1 & 16 \\
Total & 36 & 48 & 21 & 6 & 111 \\
\hline
\end{tabular}

\section{Conclusion}

The research has shown a modest presence of rural topics. There were 111 articles on rural thematic in the newspapers in the analyzed period. According to the analysis, there were no significant differences in the number of articles on rural thematic in national when compared with regional newspapers. Therefore we couldn't confirm our first hypothesis that regional newspapers cover rural topics more than those focused on the entire country. However, it has been noted that national newspapers deal more with rural issues of general national interest, while regional cover more local topics related to everyday life. Journalists of national newspapers tend to escape to sensationalism when covering rural topics, on the other hand articles in regional newspapers show balance in intonation. This is the reason for rare presence of nonsensational topics in more circulated national newspapers, which do not find interest in everyday positive rural topics. Therefore they are on the margin of those media. Thereby we can confirm our second hypothesis, according to which, the rural thematic in Croatian newspapers is neglected, except in the case they contribute to sensationalism.

Furthermore, the research results prove poor level of quality of articles with rural thematic. The newspaper articles are mostly signed by authors, but the content of articles mostly has informative character. Authors rarely use more than one source of information, and literal citing prevents deeper and personal critical interpretation of the events. It diminishes credibility of written text and shows on journalist's insufficient knowledge about the topic they cover.

The village issue in general is rarely scientifically researched in Croatian media framework. According to research it may be concluded that in spite of significant role media can have/has in developing rural areas, the thematic of village is in Croatian newspapers on the margin. This is completely contrary to the importance of rural space for national, social and economic development of Croatia. If rural thematic was more inserted into printed and public media without sensationalism, it would contribute to better affirmation of Croatian rural space and diminish quite often negative connotations about village, the rural and rural population. It is especially important that Croatian daily newspapers (as well as other media) give more space to countryside, which would reduce their highly urban content profile. That would be a step forward towards the aim of equal development of rural and urban spaces in Croatia.

\section{References}

Dragojević, S., Kanižaj, I., Žebec, I. (2006). Europska unija u hrvatskim dnevnim novinama: avis - odgoda pregovora. Politička misao, 18(3), 133-163.

Malović S. (2007). Vjerujemo li novinama?. In S. Malović (Ed.), Vjerodostojnost novina (pp. 9-20). Zagreb: ICEJ.

Ministry of Agriculture, (2008), Strategija ruralnog razvoja RH 2008.-2013. [Online] Available:

http://www.mps.hr/default.aspx?id=3652 (February 17, 2014)

Obad, O. (2004). Metode u istraživačkom novinarstvu. In I. Bešker (Ed.), Istraživačko novinarstvo (pp. 71-109). Zagreb: PressData.

Örs, Ferlal, (2008), Retrieved from The contribution of communication to rural development. [Online] Available: http:/lferlalors.files. wordpress.com/2011/02/communication-in-rural-areas.pdf (October 7, 2013)

Poler Kovačić, M. (2001). Kriza novinarstva kao kriza etike: tko je novinarski subjekt?. Medijska istraživanja, 7(1-2), 25-44.

Šačić. N. (2003). Novinarstvo u funkciji ljudskog napretka. Sarajevo: Internews B\&H.

Yadava, J. S. (1995). Rural Press: Role in Development. In V. S. Gupta \& R. Dyal (Eds.), Rural Press Problems and Prospects (pp. 1619). New Delhi: Concept Publishing Company. 